\title{
RBMS attends antiquarian book fair
}

Rare Book and Manuscript Section (RBMS) members in Southern California staffed a booth at the 33rd California International Antiquarian Book Fair, February $11-13$. Over the space of three days, collectors and librarians came to the Los Angeles Airport Marriott Hotel to admire, and often to purchase, the rare books, manuscripts, maps, prints, and other valuable and unusual materials displayed by 182 members of the Antiquarian Booksellers Association of America (ABAA).

Thanks to the generosity of ABAA and its Southern California chapter, RBMS members were given

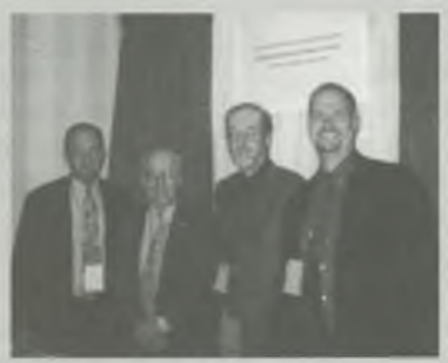

Ready to greet visitors to the 33 rd California international Antiquarian Book Fair are (I to r) Michael Thompson, ABAA; Hugh Tolford, bookfair organizer; Bill Brown, ACRL Board; and Eric Holzenberg, chair, RBM5. and scholarship in the history of the book.

ABAA's gift of space at its fairs is part of an ongoing partnership between RBMS and ABAA. The two groups are committed to exploring other joint ventures with the goal of heightening public awareness and disseminating information about the antiquarian book world and book collecting. RBMS plans to sponsor more booths at ABAA's national book fairs, and booth organizers will be recruiting members to represent the section in these venues.

RBMS received an ACRL Initiative Fund Award to support expenses relating to the booth.--Laura Stalker, Huntington Library, e-mail: lstalker@buntington.org

letter from President John Adams to Secretary of the Navy Benjamin Stoddert directing him to establish a library that would contain ". the best writing. . . on the theory and practice of naval architecture, navigation, gunnery ..."

From unique signal books, including Thomas Truxtun's personal copy of Instructions, Signals and Explanations ... (1797), to scrapbooks, like the 1936 "FDR Trip Aboard the USS Indianapolis, the library's holdings provide an eclectic array of historical material documenting the country's naval heritage. Located in the Washington Navy Yard in Washington, D.C., the library is open to the public (http://navylibrary.nhc.navy.mil).

\section{Clarification}

A news item in the January issue gave the figure of 116 institutions participating in JSTOR. This figure included only those institutions outside of the U.S. As of March 2, total institutions participating in JSTOR are 543 U.S. and 125 international (overseas) for a total of 668 . The editors regret the error. 